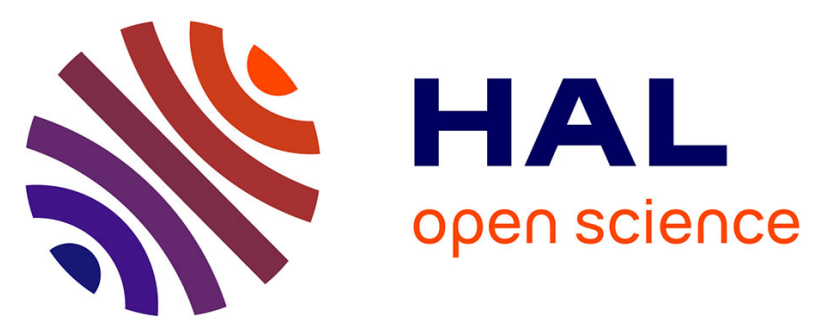

\title{
NMR metabolomic signatures reveal predictive plasma metabolites associated with long-term risk of developing breast cancer
}

Lucie Lécuyer, Agnès Victor Bala, Mélanie Deschasaux, Nadia Bouchemal, Mohamed Nawfal Triba, Marie-Paule Vasson, Adrien Rossary, Aïcha Demidem, Pilar Galan, Serge Hercberg, et al.

\section{To cite this version:}

Lucie Lécuyer, Agnès Victor Bala, Mélanie Deschasaux, Nadia Bouchemal, Mohamed Nawfal Triba, et al.. NMR metabolomic signatures reveal predictive plasma metabolites associated with long-term risk of developing breast cancer. San Antonio Breast Cancer Symposium, Dec 2017, San Antonio, TX, United States. 10.1158/1538-7445.SABCS17-P1-02-01 . hal-01790304

\section{HAL Id: hal-01790304 https://hal.science/hal-01790304}

Submitted on 2 Jun 2020

HAL is a multi-disciplinary open access archive for the deposit and dissemination of scientific research documents, whether they are published or not. The documents may come from teaching and research institutions in France or abroad, or from public or private research centers.
L'archive ouverte pluridisciplinaire HAL, est destinée au dépôt et à la diffusion de documents scientifiques de niveau recherche, publiés ou non, émanant des établissements d'enseignement et de recherche français ou étrangers, des laboratoires publics ou privés. 


\section{San Antonio Breast Cancer Symposium}

Publication Number: P1-02-01

Title: NMR metabolomic signatures reveal predictive plasma metabolites associated with long-term risk of developing breast cancer

Lucie Lécuyer ${ }^{1}$, Agnès Victor Bala ${ }^{2}$, Mélanie Deschasaux ${ }^{1}$, Nadia Bouchemal ${ }^{2}$, Mohamed Nawfal Triba ${ }^{2}$, Marie-Paule Vasson ${ }^{3,4}$, Adrien Rossary ${ }^{3}$, Aicha Demidem ${ }^{3}$, Pilar Galan ${ }^{1}$, Serge Hercberg ${ }^{1,3}$, Valentin Partula ${ }^{1}$, Laurence Le Moyec ${ }^{6}$, Bernard Srour ${ }^{1}$, Thibault Fiolet ${ }^{1}$, Paule Latino-Martel ${ }^{1}$, Emmanuelle Kesse-Guyot ${ }^{1}$, Laurent Zelek ${ }^{1}$, Philippe Savarin ${ }^{2}$ and Mathilde Touvier ${ }^{1}$. ${ }^{1}$ Sorbonne Paris Cité Epidemiology and Statistics Research Center (CRESS), INSERM U1125, French National Conservatory of Arts and Crafts, Paris 13 University, Nutritional Epidemiology Research Team (EREN), Bobigny, France; ${ }^{2}$ Chemistry Structures Properties of Biomaterials and Therapeutic Agents (CSPBAT), The National Center for Scientific Research (CNRS) 7244, Paris 13 University, Spectroscopy Biomolecules and Biological Environment (SBMB), Bobigny, France; ${ }^{3}$ Clermont Auvergne University, INRA, Human Nutrition Unit (UNH), CRNH Auvergne, Clermont-Ferrand, France; ${ }^{4}$ Anticancer Center Jean-Perrin, Clermont-Ferrand, France; ${ }^{5}$ Avicenne Hospital, Assistance Publique-Hôpitaux de Paris, Bobigny, France and ${ }^{6}$ INSERM U902, UBIAE, Evry University, Evry, France.

Body: Background: Combination of metabolomics and epidemiological approaches opens new perspectives for ground-breaking discoveries. The aim of the present study was to investigate for the first time whether plasma non-targeted metabolomic profiles, established from a simple blood draw from healthy women, could contribute to predict the risk of developing breast cancer within the following decade and to better understand the etiology of this complex disease.

Methods: A prospective nested case-control study was set up in the SU.VI.MAX cohort, including 206 breast cancer cases diagnosed during a 13y follow-up, and 396 matched controls. Non-targeted NMR metabolomic profiles were established from baseline plasma samples. Multivariable conditional logistic regression models were computed for each individual NMR variable and for combinations of variables derived by principal component analysis.

Results: Several metabolomic variables from 1D NMR spectroscopy were associated with breast cancer risk. Women characterized by higher fasting plasma levels of valine, lysine, arginine, glutamine, creatine, creatinine, and glucose and lower plasma levels of lipoproteins, lipids, glycoproteins, acetone, glycerol-derived compounds and unsaturated lipids had a higher risk of developing breast cancer. P-values ranged from $0.00007\left(\mathrm{OR}_{\mathrm{T} 3 \mathrm{vs} T 1}=0.37[0.23-0.61]\right.$ for glycerol-derived compounds) to 0.04 $\left(\mathrm{OR}_{\mathrm{T} 3 \mathrm{vs} \mathrm{T} 1}=1.61[1.02-2.55]\right.$ for glutamine $)$.

Conclusion: This study highlighted associations between baseline NMR plasma metabolomic signatures and long-term breast cancer risk. These results provide interesting insights to better understand complex mechanisms involved in breast carcinogenesis and evoke plasma metabolic disorders favorable for carcinogenesis initiation. This study may contribute to develop screening strategies for the identification of at-risk women for breast cancer well before symptoms appear. 